\title{
CRIMES THREATENING BODILY INTEGRITY (ASSAULT AND BATTERY): A LEGAL ANALYSIS OF FOUR CASES FROM THE JUDICIAL REGISTERS OF THE BAKCHISARAY/CRIMEA LAW COURT
}

\author{
Recep $C ̧ \dot{I} \breve{G} D E M^{*}$
}

\begin{abstract}
This article examines four cases from the judicial records of Bakchisary/Criema. In order to be able to establish the theoretical basis of the cases, legal doctrines are summarised paying particular attention to the principles of Hanafi law. The main purpose of this article is to compare the legal content of the cases with the Hanafi doctrines. Social relations in the society as reflected in the cases are also examined.

Key words/Anahtar kelimeler: Hanafi law, jinaya, diya, bodily integrity, assault, battery, court of law, Bakchisaray, Crimea

Bedensel bütünlüğü tehdit eden suçlar (müessir fiil): Bakçesaray/Kırım Mahkemesi Tutanaklarından dört olayın hukuksal analizi

Özet:

$\mathrm{Bu}$ çalışma, Bahçesaray mahkeme kayıtlarından dört olayı incelemektedir. Olayların hukuksal temellerini bulabilmek amacıyla, Hanefi hukuk prensipleri dahil hukuk doktrinlerinin bir özeti verilmektedir. $\mathrm{Bu}$ çalışmanın ana amacı, olayların hukuksal içeriği ile Hanefi hukuk prensiplerinin bir karşılaştırılmasının yapılmasıdır. Tutanakların yansıttığ 1 kadarıla, toplumsal ilişkilerin nasıl olduğu da incelenmektedir.
\end{abstract}

\footnotetext{
*Yrd Doç. Dr. Harran Universitesi, İlahiyat Fakültesi, İslam Hukuku A.B.D. Öğretim Üyesi. (e-posta: recep@harran.edu.tr).
} 


\section{Introduction}

This work examines several cases from the records of the Bakhchisaray law court, ${ }^{1}$ in order to find out how the court dealt with crimes involving assault and battery. Our aim here is to find out what the procedure of the court was and how the court authorities dealt with crimes. In particular, the role played by the qadi, and his primary assistant Muhzır (summoner) will be explored. ${ }^{2}$ We will also look at the composition and the function of shuhud al-hal (witnesses to the proceedings of the court).

It is worth mentioning at the outset that the reader should not expect the discussion of full legal details. Since, this is a work on the court cases; only the relevant legal principles will be given. There will be no discussion about how these principles developed and what the modern scholars say about them.

Since the court recorded only the legal content of the cases, it is quite difficult to examine them in wider concept. For this reason, except speculation, there is no way of knowing the reasons behind the cases and what happened before the cases were taken to the court. Furthermore, these are the cases came to the court, we know almost nothing about the cases resolved outside the court. Heyd, who studied Ottoman criminal law, claims that most criminal cases were dealt with by the executive authorities and that they did not make their way into the court. ${ }^{3}$ My examination of various court registers contradicts this assumption and indicates that criminal cases were brought to the attention of the court and that they were dealt with according to legal principles. ${ }^{4}$ Yet, there might have been cases resolved by the executive authorities without reference to the court.

\section{Legal Principles:}

To begin with, the principles governing bodily harm are examined in the section called 'jinaya', literally means felony or perpetration of a crime. ${ }^{5}$ Classic texts give priority to murder crimes. Having discussed them in minute detail, they examine these crimes. Since this is a study on cases involving bodily harm, I will not give the principles of murder crimes.

Muslim jurists examine this under four categories: 'amd (deliberate

\footnotetext{
${ }^{1}$ The original registers of the Bakhchisaray court are in the Saint Petersburg library in Russia. The Tatarian Library in Crimea/Ukraine holds photocopies of these records, from where I received my copies.

${ }^{2}$ See also R. Cigdem, The Register of the Law-Court of Istanbul 1612-1613: A Legal Analysis, Unpublished PhD Thesis, The University of Manchester, 2001.

${ }^{3}$ U. Heyd, Studies in old Ottoman Criminal Law, Oxford, The Clarendon Press, 1973, p. 1.

${ }^{4}$ Cigdem, The Register of the Law-Court of Istanbul.

${ }^{5}$ H. Wehr, A Dictionary of Modern Written Arabic: Arabic-English, ed. Cowan, M. J. Wiesbaden, Librairie du Liban, 1980.
} 
intent), khata (accidental homicide), ma ujriya majra al-khata (cases assimilated to mistake) and bi-sabab (indirect causation). ${ }^{6}$ Here, they do not see shibh al- 'amd as one of the categories as they do so in murder crimes.'

In the language of jurists, 'amd signifies doing harm with a deadly instrument. Khata refers to unintentional harming. In the view of jurists $k$ hata can be either in the purpose $\left(f i^{\prime} l\right.$-qasd $)$, or in the act $\left(f i^{\prime} l-f i\right.$ ' $\left.l\right)$. They see harming a person while taking him for an animal as khata in the qasd whereas they view shooting at a target but accidentally injuring a man as khata in the $f i l .^{8}$ The third category known as ma ujriya majra al-khata corresponds to injuring someone unconsciously, e.g. doing harm while sleeping. ${ }^{9}$ Bi-sabab harming refers to indirectly causing harm to someone. Here, the concept of authority plays a significant role. So, if someone injures another with his unauthorised act, he will be responsible for his action. For instance, if a person digs a well on a public property without the permission of the authorities and another falls into it injuring himself, the digger will be held responsible for inflicting harm bi-sabab.

These four categories have different outcomes. Harming someone with 'amd results in qisas (an equivalent punishment). However, this is limited to those cases in which exact equality can be assured, ${ }^{10}$ e.g. the loss of a leg from the joint, or of an ear. ${ }^{11}$ Furthermore, qisas can only be an outcome if the partners are equal, otherwise no qisas takes place. As for equality, in the view of Hanafi jurists, regardless of religious affiliation, a free person equals a free person, e.g. men vs. men. ${ }^{12}$ There is no equality and so there is no qisas between men and women or free and slave, or slave and his counter part. ${ }^{13}$ In the view of Malik (d. 179/795), and Ahmad b. Hanbal (d. 241/855), freedom and the religious affiliation are the two basis of equality. So, there is no equality between dhimmi and Muslim or free and slave. Shafi'i (d. 204/819) gives priority to freedom and the religion (Islam) and holds dhimmi vs. Muslim; slave vs. free liable, but not vice verse. ${ }^{14}$

${ }^{6}$ Ibrahim al-Halabi, Multaqa al-Abhur, Istanbul, Güryay Matbaasi, 1981, p. 459.

${ }^{7}$ Burhan al-Din al-Marghinani, Al-Hidaya, Egypt, Matba'a Mustafa al-Halabi, 1971, vol. 4, p. 166.

${ }^{8}$ Ibid. vol. 4, p. 159.

${ }^{9}$ Ibid. vol. 4, p. 159

${ }^{10}$ Ibid. vol. 4, p. 166; Halabi, Multaqa, p. 461; Abdullah b. Ahmad Ibn Qudama, al-Mughni, Beirut, Dar al-Fikr, 1992, vol. 9, pp. 411-2, 417; Ibn Rushd, Bidayat al-Mujtahid, Beirut, Dar al-Fikr, n.d. vol.2, p. 305; Muhammad al-Sharbibi al-Khatibi, Al-Mughni al-Muhtaj ilâ Ma'rifat Ma 'ani al-Alfaz al-Minhaj, pub. Mustafa al-Halabi, Cairo, 1958, vol. 4, p. 25.

${ }^{11}$ Marghinani, Hidaya, vol. 4, p. 167; Ibn qudama, Mughni, vol. 9, pp. 417, 422; Nawawi, Minhaj with Mughni al-Muhtaj, Egypt, Matba'a Mustafa al-Halabi, vol. 4, p. 27; Khatibi, Mughni al-Muhtaj, vol. 4, p. 27.

${ }^{12}$ Marghinani, Hidaya, vol. 4, p. 166.

${ }^{13}$ Ibid. vol. 4, p. 166.

${ }^{14}$ Ibn qudama, Mughni, vol. 9, p. 411; Khatibi, Mughni al-Muhtaj, vol. 4, p. 25; Ibn Rushd, Bidaya, vol. 2, p. 304; Bilmen, Ö. N. Hukuku İslamiyye ve Istılahati Frkhiyye Kamusu, 
Where there is no qisas available, normal diya ${ }^{15}$ or fixed sum compensation is to be paid, in the 'amd by the culprit himself, in the others by his 'aqila' ${ }^{16}$ (a group of people who have relation with the culprit). ${ }^{17}$ Although, as we have seen, classic texts mention aqila, Abu's-suud (d.982/1574) has the opinion that there was no aqila in the Ottoman criminal system. ${ }^{18}$ Presumably, this was the case in the Crimean Khanate. So, it was the criminal himself who pays the compensation. ${ }^{19}$

If the harm does not satisfy the requirement of qisas or diya, hukuma al' $a d l^{20}$ is to be paid for the pain suffered by the victim. This is the view of Abu Yusuf (d. 182/798). Medical expenses are also to be met by the criminal, in the view of Muhammad al-Shaibani (d. 189/805). ${ }^{21}$ In other words, these two scholars do not let the criminal get away with his crime when it did not meet the conditions of qisas or diya. In addition to this, ta zir (discretionary punishment) is always available to the judicial authorities to punish the criminal even if his crime do not satisfy the restrictive fiqh principles.

\section{The court cases}

Having summed up the juristic theories, let us now examine the court cases. We have four cases dating from 1667 to 1677 . The first three cases are about assault and battery. The fourth is a hüccet document recording permission for a medical operation.

\section{Case 1:}

$15 / 28 / 2^{22}$ The case is as follows:

A person called Ramazan, resident in the village of Harem?, a dependency of Bakhcisaray, summoned a person called Hizır b. (son of) Mehmet to the court and stated:

Istanbul, Bilmen Basimevi, 1969, vol. 3, pp. 82-5.

${ }^{15}$ Diya amounts to one of the following; one hundred camels, one thousand dinars, ten thousand dirhams, two hundred cows, one thousand sheep, or two hundred complete suit of clothes. Marghinani, Hidaya, vol. 4, pp. 177-80

${ }^{16}$ Ibid. vol. 4, pp. 166, 171, 188.

${ }^{17}$ Classic texts list 'aqila as: members of a garrison, the male members of his [offender's] tribe, the fellow workers in his craft or his confederates. Halabi, Multaqa, pp. 485-6.

${ }^{18} \mathrm{C}$. Imber, Ebu's-suud: The Islamic Legal Tradition, Edinburgh University Press, 1997, p. 247; Bilmen, Hukuku Islamiyye, vol. 3, pp. 57-8.

${ }^{19}$ Bilmen, Hukuku İslamiyye, vol. 3, p. 57.

${ }^{20}$ There is no unanimous opinion in the definition of hukuma al-'adl. Qasani (d.587/1191) relates from Karkhi (d.340/951) that it is to be decided according to the view of two doctors. Abu Bakr b. Mas'ud al-Qasani, Bada 'i al-Sina ' $i$, Beirut, Dar al-Kutub al-'Arab, 1982, vol. 5, pp. 324-5; Marghinani, Hidaya, vol. 4, p. 183; Halabi, Multaqa, p. 469; Karaman, H. Mukayeseli İslam Hukuku, Istanbul, Nesil Yayınları, 1996, vol. 3, vol. 1, p. 192.

${ }^{21}$ Marghinani, Hidaya, vol. 4, p. 186; Halabi, Multaqa, p. 471.

${ }^{22}$ This identifies the case as register 15 , page 28 and entry 2 . If you see a question mark, it means that it is illegible. 
"The said Hizir beat me hard and injured my hand. This is not good. I request that justice should be done."

After interrogation and denial, when evidence was sought from the said plaintiff, he was not able to produce evidence.

[Afterwards], the defendant was asked to take an oath.

After his oath, it is recorded that he [H1zır] was restrained (takbit).

[The case was probably recorded sometime in Rabi ' al-Awwal 1086 [5.1675], the date of the second succeeding entry. R. C.]

Shuhud al-hal: Abdulkerim Efendi, former scribe, Mehmet Efendi b. Ismail, Ramazan b. Abdullah, and others from those who are present.

Here, we see man called Ramazan filing a complaint against his counter part named Hizır. He accused Hizır of applying violence to him and doing injury to his hand. When asked, the defendant denied the accusation. The plaintiff was not able to corroborate his statement with the evidence of witnesses. In normal circumstances, this should have brought about the defendant's acquittal. Here, it did not happen. Rather, the court ordered him to be restrained. This interesting outcome suggests that the court was not satisfied with his denial, perhaps because the plaintiff came to the court with circumstantial evidence, injured hand. Furthermore, he might have been a notorious criminal and so the judge had suspicion that he committed the crime and may strike again.

The qadi is not allowed to apply the principles of jinaya where there is no evidence as in this case. Nonetheless, he is free to impose ta zir on the criminal at his discretion, if he sees it necessary. Here, it seems that the qadi turned to ta zir in restraining the defendant. The document does not make it clear the way in which he was restrained. It is however possible that he received certain number of lashes or imprisonment. Or else it was a verbal warning ordering him to mind his behaviours and attitudes and to keep peace.

The outcome of the case evidently indicates that the defendant committed the crime. He denied it in order to avert the punishment. On the question of why nobody came to bear testimony against the defendant, it is perhaps because they did not want to get involved in the case as the defendant was a nasty person and could do harm to them. In other words, he might have scared or warned them of its consequences should they bear testimony against him. It is also possible that the crime was committed in the quarter of the defendant, and the witnesses were his relatives or neighbours, so they did not bear evidence or they denied that they had witnessed the case when the plaintiff asked them to bear testimony.

On the question of why the plaintiff did not hit him back rather than take the case to the court, it is likely that the defendant was physically or 
otherwise stronger than him. So he was not able to encounter his attacks. He took it to the court hoping to get justice. However, it did not turn out as he expected, as no body bore witness against him. Nonetheless, his hopes were not totally in vain as the defendant was restrained. The plaintiff got the protection of the court and the defendant would not dear touching him again with criminal intent.

The case raises the question of what the reason behind attack was. It is highly likely that it was the result of a dispute. The defendant might have had a serious matter with the plaintiff and attempted to resolve it mutually. When he was unsuccessful in his attempts, he physically assaulted him. It is also possible that it was a sudden and unexpected attack upon a row which is related to a border dispute or a trade matter or else.

We see no Muhzır among shuhud al-hal. This suggests that the defendant was dragged into the court by the plaintiff. It is also possible that the defendant was brought to the court by the executive authorities. Since they remained outside the court, their names were not recorded.

\section{Case 2:}

$15 / 28 / 7$, The case is as follows:

A person called Halil b. Cem Ali, in the presence of a lady called Füdan bt. (daughter of) Ali, brought a case against her in the court:

"The said Füdan beat me for no reason. I request that she should be interrogated according to shari ' $a$ and justice should be done."

After interrogation, she denied [the claim].

When evidence was sought from the plaintiff, the aforesaid Halil, Ötmüş b. Sefer and $\mathrm{Hacl}$ b. Abdullah stated:

"We are witnesses and bear witness that the said Füdan beat the aforementioned Cem Ali (sic)."

When they bore legal witness, their testimony was found acceptable.

The requirement of the law has been recorded.

[The case was probably recorded sometime in Rabi ' al-Awwal 1086 [5.1675], the date of the third preceding entry. R. C.]

Shuhud al-hal: Osman Çelebi, from the quarter of Lekesne?, Hasan Efendi, Mehmet Efendi [b.] Ismail, [and] Bayram Ali [b.] Zülgafffar.

Although it is very rare, we sometimes, as in this case, come across cases in which a woman attacked and beat a man. In this case, a man named Halil was attacked and beaten by a woman called Füdan. It is likely that the beating was a mild one as the victim sustained no injuries. If he did, he would have mentioned it. 
She denied the accusation hoping to get away with her crime. She wanted to avert the punishment, but it did not turn out as she expected. Her denial of the case indicates that she was aware of the law and the procedure of the court. She might have received counselling before her trial. It is also likely that she denied the case because she was not aware of the presence of the witnesses. When they were called, she might have had a shock. Their testimony reversed her denial and ended the case in favour of the plaintiff.

The court issued a verdict of guilty without precise judgement. She might have received a ta 'zir punishment e.g. strokes or imprisonment. It is also likely that she was ordered to pay compensation for the pain which the plaintiff suffered. The latter however seems less likely.

The presence of the witnesses suggests that they saw the case but did not intervene. It is likely that since they were aware of her bad temper, they did not want to get involved in the case. Rather, they let her beat him. When the case was brought to the court, it was their testimony which made her punished for what she had done.

The document does not mention whether or not she was a married woman. If she was, why her husband did not deal with the man? There are two possible answers to this question: either he was not available when the dispute broke out or she was the master and the dominant figure of her home dealing with all sorts of problem.

Although the plaintiff claimed that the beating had been for no reason, it is highly unlikely that it was the case. Why should a woman beat a man without a reason? It is possible that it was the result of a row or a dispute over a serious matter. It is also possible that she was a bad tempered woman, and that she lost her temper for a simple reason and beat him. On the question of why he did not encounter the attack, it is perhaps because he did not want to encounter her as she was a woman.

It is not clear from the way in which the case was written where the beating took place. The presence of two witnesses suggests that it happened either in the market, in the quarter of the plaintiff or in an open place.

The presence of two efendis among shuhud al-hal suggests that the case was a serious one or they are interested in the case as it involved a woman.

This along with many other cases examined suggest that women in the Crimean society were active. They played an active role in the society. They did not sit in their home expecting their men do business for them as popularly assumed by the west. We see them everywhere in the society, in the market, in the court and so on. This clearly shows that Muslim women were not a second class citizen, having no right and no place in the society as depicted by the western intelligentsia. 


\section{Case 3:}

$11 / ? / 3$, The case is as follows:

A dhimmi [called] Korki summoned a dhimmi [called] Çoban to the court and stated in his presence:

"The said Çoban beat me. I demand justice and that he should be interrogated."

After interrogation, the said Çoban replied with a denial.

When evidence confirming his claim was sought from the said plaintiff [Korki], from the Muslims, Ali b. Buldak and Mehmet b. Osman were present in the court for deposition.

After they bore legal witness confirming the claim, a judgement according to the requirement of the law was issued.

[The case was probably recorded at the last decade of Sha 'ban 1077 [2.1667], the date of the preceding entry. R.C.]

Shuhud al-hal: Ahmet Efendi [b.] Mehmet Efendi, Habibullah al-ma 'ruf (known), Bire Mehmet b. Yahya, [and] Hasan Efendi, scribe.

Since the case involved two dhimmis, it is worth making clear a point of law that although dhimmis had autonomy in civil disputes, they were not given such powers in criminal matters. They were under obligation to take their cases to Muslim judges. ${ }^{23}$ However, they were free to resolve unserious criminal matters within their own community without making it official. However, we see the opposite as we see them frequently coming to the court for trivial matters and demanding justice.

It is also worth mentioning that dhimmis had some legal disadvantages in Muslim courts, i.e. they were no entitled to testify against Muslims. ${ }^{24}$ My examination of the court documents indicates that they were able to overcome this disadvantage by employing Muslim witnesses. If the case was within a dhimmi community as in this case, they encountered no such problem as they were legally allowed to testify against each other. ${ }^{25}$ In this case, although there might have been other dhimmis along with Muslims who saw the case, he employed two Muslims as the witnesses to the incident. As we have said, legally, their testimony carries no more weight than that of dhimmis. This selection may suggest that dhimmis preferred Muslim witnesses where there is one. If there is none, they then turned to their own people. This also indicates that dhimmis were next door

\footnotetext{
${ }^{23}$ Al-Mawardi, Abu al-Hasan, Al-Ahkam al-Sultaniyya, Beirut, Dar al-Kutub al-'Ilmiyya, 1973, p. 84; Schacht, J. An Introduction to Islamic Law, Oxford, The Clarendon Press, 1964, p. 190; Karaman, Mukayeseli, vol. 3, pp. 307-13.

${ }^{24}$ Marghinani, Hidaya, vol. 3, p. 124.

${ }^{25}$ Ibid. vol. 3, p. 124.
} 
neighbours to Muslims and that they were not segregated as suggested by $f i q h^{26}$ and that there was a social harmony between Muslims and dhimmis. Muslims did their best to help them especially in legal cases. They did not hesitate to stand as witness on their behalf against both Muslims and dhimmis. My examination of the cases indicates that the court treated dhimmis fairly and that they did not suffer injustice.

Having said that let me go over the case. Here, one claimed to have been beaten by his fellow believer. He did not report any injury. The defendant denied the accusation in order to avert the punishment. It was the testimony of the witnesses which reversed his denial and brought about his conviction. Although the precise judgement is not specified in the record, it is likely that he was sentenced to imprisonment for a few days or to several strokes as a ta'zir punishment.

The defendant's name suggests that his family was animal farmer and that he himself was also known with animal farming. This could give us a clue about the reason behind the beating. It is likely that he sold an animal to the plaintiff who delayed the payment. So a dispute broke out. It is likely that on the day of beating, the defendant came to the house of the plaintiff in order to demand the payment. When he postponed it once more, the defendant could not stand himself of attacking him violently. Perhaps because of noise or out of curiosity, the plaintiff's neighbours came out of their homes in order to see what is going on. This is how they became witness to the case.

The presence of several dignitaries in the court suggests that the plaintiff was an important man or else he was their next-door neighbour. They came to the court to ensure its fairness and to witness its procedure.

\section{Case 4:}

22/45?/7 The case is as follows:

Kerkor v. (child of) Sefer declared in the court in the presence of a surgeon [named] Patak v. Todor:

"I am suffering from hernia. Because of this, I have given my permission to this surgeon for the operation to cut it out.

[This has been] recorded.

[The case was probably recorded in the first decade of Rabi ' al-Akhir 1088 [6.1677], the date of an entry on this sheet. R.C.]

Shuhud al-hal: Hacl Mehmet from Karch?, Hacı Mahmut, Ibrahim, the said Mullah, the other surgeon Anif Efendi, Ibrahim, Mutawalli, Hasan, door keeper, [and] Abdulbaki, Muhzır.

\footnotetext{
${ }^{26}$ Ibn Nujaim, Zayn al-Din b. Ibrahim, Al-Ashbah wa al-Nazair, Beirut, Dar al-Maktaba al'Ilmiyya, 1985, vol. 4, p. 458.
} 
Here, we see a patient (Kerkor) authorising a doctor to perform a medical operation on him. It is very likely that it was the doctor who asked the patient to have his permission about the surgery documented. This is, perhaps, to avoid a possible future criminal charge, should anything go wrong. According to legal theory, organs of the body are considered to be the property of the person and under his protection. As in the case in other properties, his permission waives this protection and makes medical operation legal. ${ }^{27}$ R. Gradeva, who wrote on orthodox Christians using the evidence of the registers, observed similar cases. She writes: "The dangers awaiting a surgeon after an unsuccessful operation could bring a patient and a doctor to court." 28 This may indicate that medical operations were not performed unless a written consent was obtained from the patients. This system is still in use today in hospitals. The difference is that today patients give their consent in the hospital before they are taken to the operational theatre, and they do not go to a court or a notary to give their permission as it was in $17^{\text {th }}$ century Crimea.

The presence of a Muslim surgeon in the court while the permission for medical operation is obtained suggests that they were co-workers, and that the dhimmi wanted his Muslim colleague to be present in the court as a witness for the permission as he may need his testimony should any dispute break out. Although, the patient was a dhimmi, and the evidence of dhimmis was sufficient to establish a case, he preferred a Muslim as his witness.

The presence of several dignitaries (a Mullah, an Efendi, a Mutawalli) in the court suggests that the surgeon was a known person in the circle of bureaucrats. The presence of a Muhzir among shuhud al-hal suggests that the patient was brought to the court by the executive authorities. Since he was a patient, the Muhzır gave him a hand and carried him to the court.

\section{Conclusion:}

As we have seen, the court served not only as a place where the disputes are resolved but also as a premise where notary documents are issued. Although the outcome of the cases was not clearly recorded as they were written in short form 'a judgment was passed according to the requirement [of the law]', they provide us valuable information about the procedure of the court. Furthermore, as the first case suggests, we learn from the entries that the court did not follow the law to the letter. It did not strictly observe the legal principles as they appear in classic figh books. Rather the court is interested in getting justice done.

\footnotetext{
${ }^{27}$ Muhammad al-Khurashi, [Sharh] al-Khurashi 'alâ Mukhtasar Saydi al-Khalil, Beirut, Dar al-Sadr, 1900, vol. 8, pp. 110-1; Bilmen, Hukuku Íslamiyye, vol. 3, pp. 80, 113.

${ }^{28} \mathrm{R}$. Gradeva, "Orthodox Christians in the Qadi Courts: The Practice of the Sufia Sheriat Court, Seventeenth Century", Islamic Law and Society 4/1 (January 1997), p. 65.
} 
The dhimmis following the requirement of the law that criminal matters have to be dealt with by Muslim judges took their cases to the Muslim court where they were treated fairly and impartially. Although they had some legal disadvantages such as not being entitled to bear testimony against Muslims, they lessened it via social harmony with Muslims as we see them living and working next to each other. In addition, Muslims did their best to help them especially in legal matters by standing witness. Not only in civil disputes but also in criminal cases Muslims stood as witness in the court for dhimmis.

In this work, we have seen an interesting case in which a man was battered by a woman. Although further research is required in order to find out how widespread it was, this give us a clue about the role of women in the society. They were not segregated in the society. On the contrary, we see them playing an active role in the society, participating in every aspect of social life. This contradicts the western scholars depiction of Muslim women as second class citizen, having no right and no place in the society. 